\title{
Organizational Culture as a Root of Performance Improvement: Research and Recommendations
}

\author{
Raduan Che Rose \\ Universiti Putra Malaysia \\ E-Mail: rcr@putra.upm.edu.my \\ Naresh Kumar \\ Universiti Putra Malaysia \\ E-Mail: naresh@putra.upm.edu.my \\ Haslinda Abdullah \\ Universiti Putra Malaysia \\ E-Mail: hba@putra.upm.edu.my \\ Goh Yeng Ling \\ Universiti Putra Malaysia \\ E-Mail: gyl@gmail.com
}

\begin{abstract}
Internationalization of business may perhaps force not merely the restructuring of cultural values but to consider the overture of different cultural practices which perhaps leads to a superior organizational performance. Literatures pertaining to organizational culture constantly reinforce that culture is imperatives for organizational change efforts, deployment of human resources and to a large extent aid in sustaining competitive edge. Indeed leaders are challenged to revolutionize their organizational culture as to address the business world mutiny. This article attempts to provide some insights into the organizational culture and how it might assist in increasing organizational performance.
\end{abstract}

Keywords: Culture, Performance, Multinational Corporation, Malaysia 


\section{INTROUDUCTION}

Organizational culture facilitates the acceptable solution to know the problems, which members learn, feel and set the principles, expectations, behaviour, patterns, and norms that promote high level of achievements (Marcoulides \& Heck, 1993; Schein, 1992). It has been observed that in many foreign based organizations, business oriented values are derived consciously and unconsciously from the culture of its founder (Asma, 1996). In a similar vein, Harrison (1994) alluded that the organizational cultures may

vary based on the role, power structure and the capability to manage organization by the expatriates' managers who bring their own national cultures to the workplaces. For instance, American cultural values have affected the Exxon Mobil, IBM, and Dupont meanwhile Japanese cultural values pervade Mitsui, Hitachi, Sony and Nissan. These organizations bring along their "cultural baggage" in the form of systems, procedures, and techniques, similar to their home country wherever they do business and continue to function. For instance, Japanese culture is more concerned about the collectivism, lifelong commitment to their organizations and samurai spirit applied in their workplaces. On the other hand the American corporations place a great emphasis on individual based reward systems rather than group rewarding (Asma, 1996).

Due to the globalization challenges, many multinational companies (MNCs) seek business expansion in the foreign countries through direct foreign investment and aggressively establishing subsidiaries with the purpose to maximize the value of shareholders' equity. The effort of developing countries in particular had brought foreign direct investment from countries such as the United States, Japan, Europe, Korea, and Germany. Nevertheless, many MNCs from developing countries have set up their operations abroad, for example MNCs from Malaysia such as Petronas, OYL, Pensonic, and FCS system. It is a common scenario that foreign companies in the developing countries are managed or headed by expatriate managers from the home country. Patrick, Felicitas and Albaum (2005) maintained by saying that the management style adopted by expatriate managers' is in accordance with their home country's culture. It would be interesting to discover to what extent do MNCs whose cultures may well equivalent of their home country, experiences performance improvement when they operate in another country with diverse cultural orientations. Indeed the study of organizational culture and performance is advantageous since the cultural values are observable and measurable. Thus it can be compared across organizations and directly related to individual and organizational performance (Siehl \& Martin, 1998). Undoubtedly the organization's 
performance is a function of the potential return to the inculcation of strong culture into the organization's systems enabling it to execute its routines. It is interesting to verify the applicability of Hofstede's measures of culture which was originally design to evaluate culture at national level, in measuring organizational power distance, individualism, uncertainty avoidance, and masculinity (Pratt \& Beaulieu, 1992). Pratt, Mohrweis, and Beaulieu (1993) recommended that future research "could usefully benefit from using the measure of organizational culture recently developed by Hofstede et al. (1990)" (p.627). Moreover Hofstede's cultural framework has been replicated and validated by many studies abroad over the time (Chow, Shields \& Wu, 1999; Harrison \& McKinnon, 1999).

Scholars and practitioners have constantly argued that both financial and nonfinancial measures should be used to determine the organizational performance (Harold \& Darlene, 2004; Kaplan \& Norton, 1992; Rajendar \& Jun Ma, 2005). Performance is a broader indicator that can include productivity, quality, consistency, and so forth. On the other hand, performance measures can include results, behaviors (criterion-based) and relative (normative) measures, education and training concepts and instruments, including management development and leadership training for building necessary skills and attitudes of performance management (Richard, 2002). Furthermore, Kotter and Heskett (1992) found that companies with "adaptive values" are strongly related with superior performance over a long period of time as compared to just short-term performance. This has been also supported by both Collins and Porras (1994) and De Geus (1997) in their work in long lived, financially successful companies. Thus in studying the relationship between cultural and performance, it is vital that both financial and non financial measures are used to get a more comprehensive results.

\section{RELATED LITERATURE}

\section{Cultural Dimensions}

The pioneering work on cultural measurement could be credited to Hofstede (1980). In the earlier stage, Hofstede identified four dimensions of culture and highlights the most important culture differences in a multinational company. The four dimensions are individualism versus collectivism, power distance, uncertainty avoidance and masculinity and femininity. These four dimensions were initially detected through the comparison of the value among the employees and managers working in 53 national subsidiaries of the IBM Corporation. 
A fifth dimension, long-term versus short term orientation was added based on a study among the students in 23 countries by using the questionnaire prepared by the Chinese Value Survey in Hong Kong (Hofstede \& Bond, 1998, 1987). The data suggest that China is somewhat vary from the western countries such as the United Kingdom and United States on dimensions of masculinity and uncertainty avoidance. Furthermore there is a substantial gap between western and eastern countries on power distance, individualism and long-term orientation. However, some of the reviewers have point out the shortcoming from the research taken by Hofstede in measuring a single organization across the countries, in order to make the national culture differences (Tierney, 1990; Korman, 1985; Robinson, 1983). Besides that, the reviewers also pointed out that Hofstede analysis may be artifacts during the survey conducted at that period of time and focuses on attitude surveys (Sondergaard, 1994; Schooler, 1983). Even though Hofstede's study has been criticized, it has been widely acknowledged by scholars and practitioners in the field of organizational behavior (Sondergaard, 1994).

Schwartz (1994) proposed a cultural value symbolizing the relationship between personality and cultural factors. His model was developed based on the Hofstede (1980) and Kluckhohon and Strodbeck's (1961) studies and data were collected from respondents across 38 countries. There are two dimensions in Schwartz model: conservatism versus autonomy (affective and intellectual) and self-enhancement (hierarchy and mastery) versus self-transcendence (egalitarian commitment and harmony). According to Schwartz (1994), the two broad cultural archetypes of societies with different assumptions about the life and work can be characterized as contractual culture and relationship cultures. China and United States of America have contrast values in Schwartz model. For instance, in the Chinese culture, the observed values are such as collectivism, larger power distance, strong uncertainty avoidance, long-term orientation, outer directed relationship and conservation. In contrast, in the western culture, people are more towards individualism, small power distance, weak uncertainty avoidance, short-term orientation, and inner-directed, contractual, autonomy, tension between mastery and egalitarian commitment / harmony.

Similarly, Trompanaars' (1993), identified seven dimensions which it involves 30 companies in 50 different countries. There are five dimensions under the broad heading of relationships with people, which consists of universalism versus particularism, individualism versus communitarians, neutral versus emotional, specific versus diffuse and achievement versus ascription. However, for the six dimensions, it concentrates on 
attitudes to time and the seventh dimension is attitudes to the environment. Trompenaars seven dimensions model can be a good supported for Hofstede's model. For instance, Trompenaars' dimension of attitudes to time is related to Hofstede's dimension of individualism and long-term orientation in the individualist culture such as United Kingdom. On the other hand, in the collectivist cultures such as China, Chinese typically more to long-term orientation according to Trompenaar's study (1993).

Md. Zabid, Anantharaman and Raveendran (1997) studied the relationship between corporate culture and work values in Malaysian organizations. The authors assessed the characteristics of corporate culture among the dominant ethic groups, which are Malays, Chinese and Indians. The researchers examined the corporate culture and work value by using Hofstede's four dimensions and work values proposed by Asma (1996). The finding of the research indicated that Malays, Chinese and Indians are more to masculinity dimension, collectivism, high uncertainty avoidance and low power distance. Besides that, the findings shown significant differences between dominate ethnic organizations in their work values in terms of work commitment, loyalty, respect for hierarchy, harmony, preserving face and spirituality. It can be concluded at this point that organizational culture comprises of unique quality or character of a company meanwhile the managers are challenged to search for the "strong" culture that probably could improve the organizational effectiveness because it is strongly believed that there are cause and effect associated with each cultural dimensions.

\section{CULTURE AND PERFORMANCE}

A high degree of organization performance is related to an organization, which has a strong culture with well integrated and effective set of values, beliefs and behaviors (Cameron \& Quinn, 1999; Deal \& Kennedy 1982; Denison, 1990; Juechter \& Fisher, 1998; Kotter \& Heskett, 1992). However, many researchers noted that culture would remain linked with superior performance only if the culture is able to adapt to changes in environmental conditions. Furthermore, the culture must not only be extensively shared, but it must also have unique qualities, which cannot be imitated (Lewis, 1998; Lim, 1995; Ouchi, 1981; Pascale \& Athos, 1981). Several empirical studies have supported the positive link between culture and performance (Calori \& Sarnin, 1991; Gordon \& DiTomaso, 1992: Kotter \& Heskett, 1992). Moreover, there are recent studies done by Chatman and Jehn (1994), Denison and Mishra (1995) and Kotter and Heskett (1992), have contributed significantly to the field of culture and performance studies whereby 
culture is being treated as variable for a specific research purpose. For example, Denison and Mishra (1995), utilizing a more rigorous methodology, discovered that cultural strength was significantly correlated with short-term financial performance. Schneider (1990) also found that the organizations focuses clearly on the cultures are more successful. It is because focused cultures provide better financial returns, which include higher return on investment (ROI), higher return on assets (ROA) and higher return on equity (ROE). The finding of a study also has been reported that industry moderates the link between corporate culture and performance (Gordon \& Christensen, 1993). These findings have advanced understanding of the determinants and performance effects of corporate culture. But they go away unreciprocated the applicability of existing results across national boundaries. There are some aspects of corporate culture may enhance performance in one national setting, but they may not be effective, and may even be dysfunctional, in another (Chow, Kato \& Merchant, 1996; Lincoln \& Kalleberg, 1990; Steers, 1989). Thus, one of the main reasons for the common popularity and interest in the study of organizational culture is due to the argument or assumption that certain organizational cultures lead to superior organizational performance.

\section{METHOD}

This study has been initiated to examine the relationship between culture and performance in the American, Japanese, European and Malaysian MNCs operating in Malaysia. The necessary data to fulfill the research objective were obtained from selfadministered questionnaires. The items were designed to examine the organizational culture in four vital areas following Hofstede's (1980) culture dimensions, namely, individualism and collectivism; power distance; uncertainty avoidance and masculinity and femininity. Sixteen items were used to assess the organizational culture on sevenpoint scale ranging from (1) strongly disagree to (7) strongly agree. The items were adapted from Rajendar and Jun Ma's (2005) work. For the purpose of measuring the organizational performance, nineteen items were developed based on the work of Rajendar and Jun Ma (2005). Respondents were asked to indicate their agreement and disagreement on a seven-point scale. The five performance indicators are: financial perspective, customer perspective, internal business perspective, innovation and learning perspective and technological assessment.

The respondents for this study consist of managers or executives of the American, European, Japanese and Malaysian MNCs located in Malaysia. All the respondents are 
from high technology industry such as electronic, electric, and information technology. A total of 240 questionnaires were mailed to the respective companies and only 133 completed questionnaires were received giving a responses rate of 55\%. The collected data was coded and analyzed using SPSS for windows.

\section{FINDINGS AND DISCUSSION}

The mean scores were calculated to observe to what extent the American, European, Japanese and Malaysian MNCs inculcate Hofstede's cultural dimensions. The findings revealed that American and European MNCs are skewed towards a culture of individualism, low power distance, low uncertainty avoidance, and femininity. On the other hand, collectivism, high power distance, high uncertainty avoidance, and masculinity best describe the culture of Japanese and Malaysian MNCs. Indeed several other studies have reported in a similar vein of this study (Bhaskar, 1990; Helen, Roland \& Philippe de Woot, 1994; Helen 2000; Hofstede, 1980; Kamal Bashah 1988; Keith \& Hans, 1989; Keith \& Miyuki, 2004; McLaren 1998; Rajendra \& Jun Ma, 2005). Based on the findings of this study as well as other studies, it is quite realistic to conclude that expatriate managers in managing their subsidiaries abroad while giving rooms to adapt the host countries culture, tend to inculcate more of their home cultural values.

The findings also shows that American and European MNCs were performing well in all the five performance dimensions compared to Japanese and Malaysian MNCs. Moreover the findings of this study indicate that those with high scores in individualism, low power distance, low uncertainty avoidance and femininity would have higher mean scores in organizational performance. Thus this study supports the findings of Cameron and Quinn (1999) and Kotter and Heskett (1992). Schneider, Hanges, Smith \& Salvaggio (2003) contended that healthier employee attitudes were prerequisites to financial and market performance advancement. Therefore, it could also be perceived that high scores in financial and customer perspectives between American and European MNCs based in Malaysia are credited to superior employee attitudes. Table 1 presents the mean scores of Hofstede's cultural dimensions and organizational performance dimensions for the selected sample of this study. 
Table 1 Mean Scores of Organizational Culture and Performance Dimensions

\begin{tabular}{lcccc}
\hline \multirow{2}{*}{ Dimensions } & \multicolumn{4}{c}{ MNCs } \\
\cline { 2 - 5 } & American & European & Japanese & Malaysian \\
\hline Organizational Culture: & & & & \\
& & & & \\
Individualism/Collectivism & 4.9957 & 4.8889 & 4.4722 & 3.3186 \\
Power Distance & 5.3590 & 5.4250 & 4.6833 & 3.4926 \\
Uncertainty Avoidance & 5.5726 & 5.2111 & 4.7778 & 3.4706 \\
Femininity/Masculinity & 5.4530 & 5.0889 & 4.5000 & 3.5588 \\
& & & & \\
Organizational & & & & \\
Performance: & & & & \\
& 5.3932 & 5.6889 & 4.4111 & 4.4216 \\
Financial Perspective & 5.6068 & 5.3444 & 5.1111 & 4.3235 \\
Customer Perspective & 5.0043 & 5.2389 & 4.5944 & 3.8333 \\
Internal Business Perspective & 5.3013 & 5.1250 & 4.1083 & 3.7794 \\
Innovation \& learning & 5.7607 & 5.7222 & 3.8333 & 4.6569 \\
Perspective & & &
\end{tabular}

Table 2 present the correlation results between the four dimensions of organizational culture and performance. The overall results show that American and Malaysian MNCs have significant relationships between all the four cultural dimensions and organizational performance. There is a positive correlation between two of the cultural dimensions (individualism and collectivism; and power distance) with organizational performance in European MNCs . On the other hand, only uncertainty avoidance showed a significant relationship with organizational performance in Japanese MNCs. Generally this study together with many other earlier researches (Seihl \& Martin, 1998; Denison, 1990; Deal \& Kennedy, 1982; Maani, Putterill \& Stuti, 1994; Petty, Beadles \& Lowery, 1995; Lim, 1995) has revealed that there is a possible relationship between organizational culture and performance. 
Table 2 Relationship between Cultural dimensions and Overall Organizational Performance

Dimensions

\begin{tabular}{lcccc}
\cline { 2 - 5 } Individualism/Collectivism & American & European & Japanese & Malaysian \\
Power Distance & $0.550^{* *}$ & $0.737^{* *}$ & 0.184 & $0.440^{* *}$ \\
Uncertainty Avoidance & $0.388^{*}$ & $0.466^{* *}$ & 0.296 & $0.557^{* *}$ \\
Femininity/Masculinity & $0.464^{* *}$ & 0.316 & $0.419^{*}$ & $0.577^{* *}$ \\
** & $0.533^{* *}$ & 0.030 & 0.057 & $0.568^{* *}$ \\
* Correlation is significant at 0.01 level (2-tailed). & & & \\
Correlation is significant at 0.05 level (2-tailed). & & &
\end{tabular}

\section{CONCLUSION}

The literature on organizational culture and performance revealed that companies that know how to develop their cultures in an effective way most probably have the benefit of advancement in productivity and the quality of work life among the employees. Indeed, employees must absorb the organizational culture at the maximum strength and the top management should provide a precise guideline and direction to motivate the employees in achieving the company's objectives. The expatriate managers in the MNCs are anticipated to learn and identify the work values and cultural behaviors of the employees within the organization and try to adapt into that culture across the countries. This seems to be possible even though the expatriate managers maybe influenced by their own national culture. To some extent the researchers believe that national culture is not a barrier for foreign subsidiaries to operate abroad. This is transparent from the findings of this study that in average performance of American, European, and Japanese MNCs are higher than Malaysian MNCs. On the basis of this findings, Malaysian MNCs would spread their wings by developing more subsidiaries abroad with confident since culture of the host countries could be tackled tactically to improve business performances. In the business performance management, what matters is how we manage the system and people in it, not solely depend to pure adoption of culture whether host or home counties culture. Future research is significant in examining the relationship between culture and performance among multinational companies (MNCs) in different business sectors. It should be aimed to ascertain the culture adopted by local and foreign multinational companies because most of those companies might face the culture diversities when involve in the international business expansion. In view of the small sample, generalizability of the findings of this study to a wider population is impossible. Thus drawing of any conclusion from this study should be done carefully. This is seen as the 
limitation of the study.

\section{REFERENCES}

Asma Abdullah (1996). Going Glocal: Cultural Dimensions in Malaysian management, Malaysian Institute of Management (MIM), Kuala Lumpur, Malaysia.

Bhaskar Chatterjee (1990). Japanese Management: Maruti and the Indian Experience, Sterling Publishers Privated Limited, New Delhi, India.

Calori, R. \& Sarnin, P. (1991). Corporate Culture and Economic Performance: A French Study, Organization Studies, 12(1): 49-74.

Cameron K., \& Quinn, R.E. (1999). Diagnosing and Changing Organizatinal Culture: Based on the Competing Values Framework. Reading, MA: Addison-Wesley.

Chatman, J. A. \& Jehn, K.A. (1994). Assessing the Relationship between Industry Characteristics and Organizational Culture: How Different Can You Be? The Journal of Management, 37: 522-553.

Chow, C., Kato, Y. \& Merchant, K. (1996). The Use of Organizational Controls and their Effects on Data Manipulation and Management Myopia: a Japan vs. U.S. comparison. Accounting, Organizations and Society, 21: 175-192.

Chow, C.W., Shields, M.D., \& Wu, A. (1999). The importance of national culture in the design of and preference for management controls for multi-national operations. Accounting, Organizations and Society, , 24: 441-461.

Collins, J.C. and Porras, J.I. (1994), Built to Last: Successful Habits of Visionary Companies, Harper Business, New York, NY.

Deal, T.E \& Kennedy, A. A. (1982). Corporate Cultures. Menlo Park: Addison Wesley Publishing Co.

De Geus, A. (1997), The Living Company: Habits for Survival in a Turbulent Business Environment, Harvard Business School Press, Boston, MA.

Denison, D.R. (1990). Corporate Culture and organizational effectiveness. John Wiley \& Sons, New York, NY.

Denison, D.R. and Mishra, A.K. (1995). Toward a theory of organizational culture and effectiveness. Organization Science, 6 (2): 204-223.

Gordon, G. G. and E. Christensen. (1993). Industry Influences on the Relationships between Management Culture and Performance. Paper presented at the National Meeting of the Academy of Management, Atlanta, GA.

Gordon, G. \& DiTomaso, N. (1992). Predicting Corporate Performance from 
Organizational Culture. Journal of Management Studies, 29(6): 783-798. Harrison, G. (1994). Culture and Management, Australian Accountant, 64 (10) : 14-22. Harrison, G.L., \& McKinnon, J.L. (1999). Cross-cultural research in management control systems design: a review of the current state. Accounting, Organizations and Society, 24: 483-506.

Harold D. F. and Darlene, B.S. (2004). Managing for Value: Developing a Performance Measurement System Integrating Economic Value Added and the Balanced Scorecard in Strategic Planning, Journal of Business Strategies, 21(1): 1-17.

Helen, B., Roland, C. and Philippe de Woot (1994). Euro Management: A New Style for the Global Market, Insights from Europe's Business Leaders, 1st Edition, the Euro Business Publishing Network, UK.

Helen, D. (2000). Management: Managing Across Borders and Cultures, Third Edition, Prentice Hall, Upper Saddle River, New Jersey, New York.

Hofstede G. (1980). Culture's Consequences: International Difference in Work Related Value, London, Sage Publication.

Hofstede G, Bond MH (1998). The Confucius Connection: from Cultural Roots to Economic Growth, Organ Dyn, pp. 5-21.

Hofstede G, Bond M.H. (1987). The Chinese Culture Connection. Chinese Values and the Search for Culture-Free Dimensions of Culture. Journal of Cross Cultural Psychology, 18(2) : 143-164.

Juechter, W.M., and Fisher.C.et.al. (1998). Five Conditions for High Performance Cultures, Training and Development, 52(5) : 63-68.

Kamal Bashah (1988). Organizational Culture: Organizational Adaptability and ChangeA Study of PETRONAS, Doctoral Dissertation, University of California, USA.

Kaplan, R.S. and Norton, D.P (1996). The Balance Scorecard: Translating Strategies into Action. Harvard Business School Press, Boston, USA.

Keith, J. and Miyuki, T. (2004). The Changing Face of Japanese Management, 1st Edition, Routledge Publisher, London.

Keith T. and Hans W. (1989). Towards European Management, 1st Edition, Pitman Publishing, London.

Kluckhohn, F.R., and Strodtbeck F.L. (1961). Variations in Value Orientations, CT: Greenwood Press.

Korman, A.K. (1985). Culture's consequences: International Differences in Work Related Values, Book Review, Journal of Occupational Behaviour, 6(3) : 243-244. 
Kotter, J.P. and Heskett, J.L. (1992). Corporate Culture and Performance, Free Press, New York.

Lewis, D. (1998). How Useful a Concept is Organizational Culture? Strategic Change, 7: 261-276.

Lincoln, J. \& A. Kalleberg (1990). Culture, Control, and Commitment. Cambridge University Press, Cambridge, England.

Lim, B. (1995). Examining the Organizational Culture and Organizational Performance link, Journal of Leadership and Organizational Leadership, 16(5) : 16-21.

Maani, K.E., Putterill, M.S., and Sluti, D.G. (1994). Empirical analysis of Quality Improvement in Manufacturing. Asia Pacific, Journal of Quality Management, 3(1): $5-23$.

Marcoulides, G. and Heck, R.H. (1993). Organizational Culture and Performance: Proposing and Testing a Model, Organizational Science, 4(2) : 209-223.

McLaren. M.C. (1998) Interpreting Cultural Differences. Peter Francis: Norwich, UK.

Md. Zabid Abdul Rashid, R.N. Anantharaman and Jaina Raveendran (1997). Corporate Cultures and Work Values in Dominant Ethic Organizations in Malaysia, Journal of Transnational Management Development, 2(4): 60-72

Patrick S. P, Felicitas U. E. \& Albaum, G. (2005). A Comparative Study of the Management Styles of Marketing Managers in Australia and the People's Republic of China. International Marketing Review, 22(1): 34-47.

Petty, M.M., Beadles II, N.A., Lowery, C.M. (1995). Relationship between Organizational Culture and Organizational Performance, Psychological Reports, 76(2): 483-492.

Ouchi, W.G. (1981). Theory Z. How American Business Can Meet the Japanese Challenge, Addison-Wesley, Reading, MA.

Pascale.R.T. and Athos A.G. (1981). The Art of Japanese Management: Applications for Merican Executives. New York: Simon\& Schuster.

Pratt, J., \& Beaulieu, P. (1992). Organizational culture in public accounting: size, technology, rank, and functional area. Accounting, Organizations and Society, 17: 667684.

Pratt, J., Mohrweis, L.C., \& Beaulieu, P. (1993). The interaction between national and organizational culture in accounting firms: an extension. Accounting, Organizations and Society, 18: 621-628.

Rajendar and Jun Ma (2005). Benchmarking Culture and Performance In Chinese 
Organizations, Benchmarking An International Journal, 12(3) : 260-274.

Richard, C. (2002). Experiments with New Teaching Models and Methods.

International Public Management Review.

Robinson, R.V. (1983). Greet Hofstede: Culture's Consequences of Performance Measurements, Administrative Science Quarterly, 1(2) : 240-247.

Schien, E.H. (1992). Organizational Culture and Leadership, 2nd Edition, San Francisco; Jossey-Bass.

Schneider, B., Hanges, P. J., Smith, D. B., \& Salvaggio, A. N. (2003). Which comes first: Employee attitudes or organizational financial and market performance?

Journal of Applied Psychology, 88, 836-851.

Schooler, C. (1983). Culture's Consequences, Book Reviews, Contemporary SociologyA Journal of Reviews, 12(2): 167.

Schwartz S.H. (1994). Beyond Individualism/ Collectivism: New Cultural Dimensions of Values. Thousand Oaks, CA: Sage Publication.

Schneider, B. (1990). Organizational Climate and Culture, Jossey-Basss, San Francisco, CA.

Siehl, C. \& Martin, J. (1998), Measuring Organizational Culture: Mixing Qualitative and Quantitative Methods, in Jones, M.O, et al. (Eds), Inside Organizations: Understanding the Human Dimension, Sage Publications, Newbury Park, CA, pp. 79-103.

Sondergaard, M. (1994). Hofstede Consequences- A Study of Reviews, Citations and Replications, Special Issue on Cross-national Organization Culture, European Group for Organizatinal Studies, 15(3) : 447-456.

Steers, R. (1989). Organizational Science in a Global Environment. In Osigweh (Ed.) Organizational Science Abroad. New York: Plenum, pp. 293-326.

Tierney W.G. (1990). Assessing Academic Climates and Cultures, Jossey-Bass, San Francisco, CA.

Trompanaar F. (1993). Riding the Waves of Culture. London: Economist Books. 
Contemporary Management Research 56 